This Section of Epidemiology and Psychiatric Sciences appears in each issue of the Journal and is dedicated to all forms of creative production born of an intimate and individual urge, often secretive, unbound from the conventional art system rules. Through short descriptions of the Outsider art work of prominent artists and new protagonists often hosted in community mental health services, this section intends to investigate the latest developments of the contemporary art scene, where the distances between the edge and the center are becoming more and more vague.

Carole Tansella, Section Editor

\title{
Martin Erhard - upper world and underworld. Order and perversion
}

\section{G. Dammann}

Psychiatric Clinic of Münsterlingen, Psychiatric Services of Thurgovia (Academic Teaching Hospital of the PMU Salzburg), Münsterlingen, Switzerland

Received 10 July 2016; Accepted 14 July 2016; First published online 11 August 2016

Key words: Outsider art, personality disorders cluster a paranoid schizoid schizotypal, psychoanalysis and psychodynamic therapies, sexual deviations, violence/aggression.

In the Art Brut-collection of the Austrian painter Arnulf Rainer, which was exhibited in the Museum De Stadshof Zwolle in 1996/1997, there are four peculiar drawings by an artist labelled as 'anonymous' (Museum De Stadshof, 1996).

In a highly systematically ordered fashion, these drawings offer a glimpse at a gargantuan subterranean location hosting every kind of sexual deviation and torture. A combination of lair, prison, reformatory and brothel provides insight into a panopticon of perversion. Some rooms bear names like 'rape chamber' or 'wheel of pinching and shame'. In various cells, it becomes clear that the targets of the devious schemes are children ('resting rooms: first to sixth grade'). In some designated areas, the sexual activities include dogs and goats. However, there is also a coffee room, an entertainment room featuring a cinema and classrooms complemented by offices for teachers. The only aspects of the dungeon actually sketched out are floor plans, corridors, tunnels and other

Address for correspondence: Dr G. Dammann, Psychiatric Clinic of Münsterlingen, Seeblickstr. 10, CH-8596 Münsterlingen, Switzerland. (Email: gerhard.dammann@stgag.ch) architectural features. The artist neither depicts men, women, children or animals, nor the torture devices. It is the short descriptions alone that evoke the picture of cruel torturing and create a contrast to the scrupulously clean geometric style.

This horrific location is located $400 \mathrm{~m}$ below the surface, accessible only through a single vertical shaft into the earth. It is characterised by its creator simply as the 'great amusement park' or the 'paradise of pleasure'. When it comes to naming the gruesome events taking place there, the artist is not at a loss for words either: 'Where one atrocity follows the other', unaware 'adolescent adventurers' are killed in various ways by the 'most wicked libertines', who 'take pleasure in sex murder'. It is the 'home of love and sin imbedded in the valley of thickly overgrown foothills'.

Fifteen years after the drawings came into possession of Arnulf Rainer, a considerable omnibus volume (provided by the same former neighbour of the artist who sold the first share of drawings to Rainer) was acquired and later sold by Galerie Susanne Zander in Cologne. In the process, the identity of the - thus no longer 'anonymous' - artist was revealed. The creator of the drawings, which must have required an enormous amount of time to produce, was identified as 


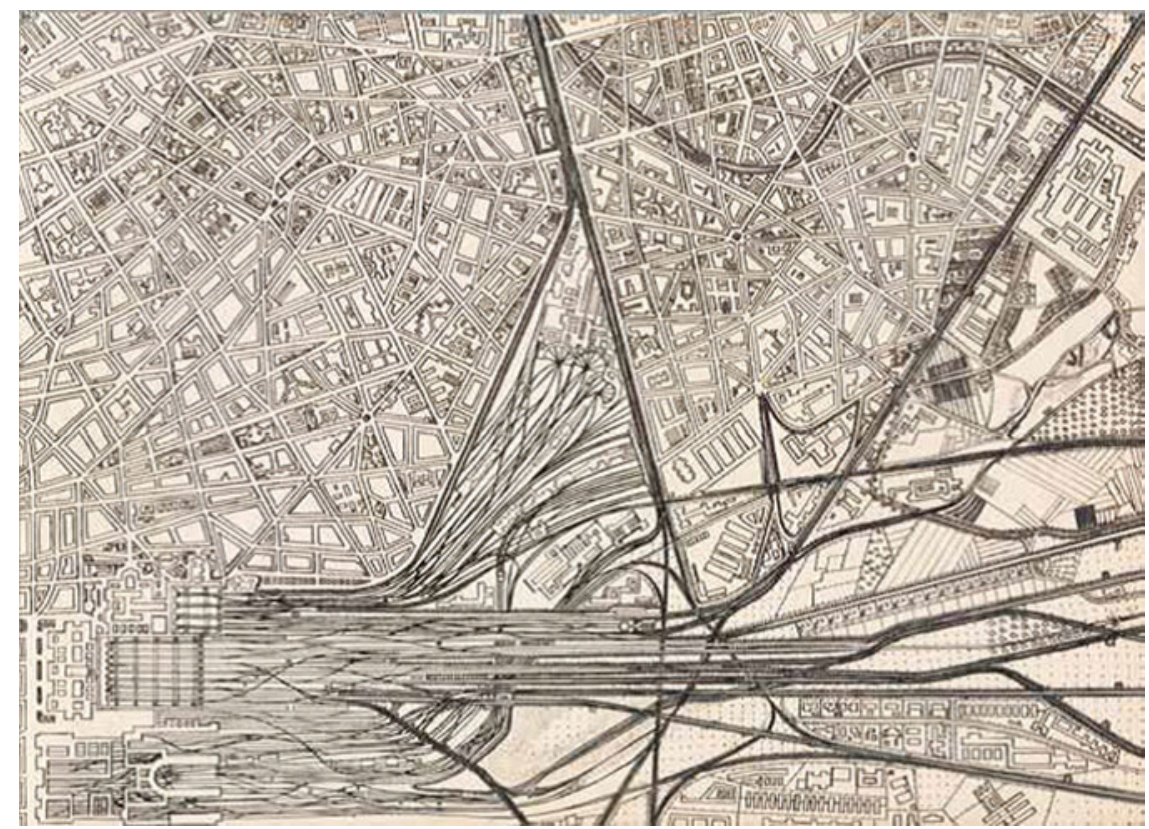

Fig. 1. Martin Erhard (1907-1979) untitled, undated [railroad line] first drawing (volume of 58 sheets) pencil and Indian ink on paper each ca. $50 \times 70 \mathrm{~cm}$.

Martin Erhard, an Upper Bavarian miner and eccentric, who lived in Peissenberg (Weilheim-Schongau) from 1907 to 1979 . To date, there is no known photograph of him.

The core of the oeuvre consists of 58 numbered drawings in large format (in most cases, $50 \times 70 \mathrm{~cm}^{2}$ ) of a sort of railroad line running through a diversity of landscapes and ending in a train station. Laying out the track in its entirety requires a significant amount of space (roughly $75 \times 75 \mathrm{~m}^{2}$ ). The first couple of sheets are meticulously executed and bear resemblance to geographical-topographical drawings of obsessive accuracy (see Fig. 1). Again, no human being is to be seen. The world Erhard puts on display is rich and void at the same time. Some of the later sheets depict nothing but the railroad line. There is reason to assume that Erhard simply lacked the time to flesh out these sketches. The contrast between the initial density

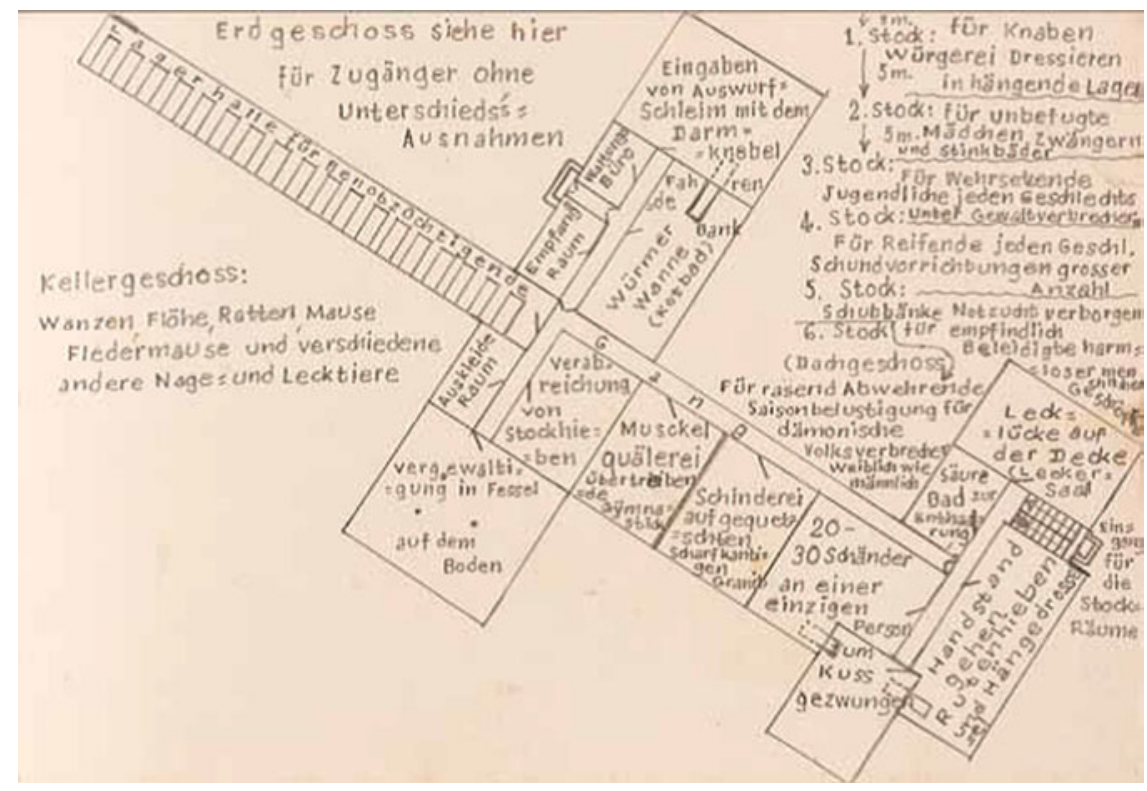

Fig. 2. Martin Erhard (1907-1979) „Kellergeschoss: Wanzen, Flöhe, Ratten ...”, undated pencil on paper $20.5 \times 30 \mathrm{~cm}$. 
and the degree of abstraction in the later drawings has its own special kind of aesthetic allure. The seemingly endless railway track can be seen on the Internet in the 2012 short movie 'Home of Love and Sin' (Galerie Susanne Zander, 2012).

Little is known about the life of Martin Erhard. Interestingly enough, however, there are various parallels between the content of the drawings and the biography of their creator. Erhard worked in an underground mine for many years. The mine in Peissenberg (Biller \& Stippel, 2006) focused primarily on the extraction of pitch coal and, to a lesser degree, the recovery of marlstone for cement production. The mine featured more than $100 \mathrm{~km}$ of underground tracks. It operated from 1837 to 1971. In 1963, up to 3913 miners worked there - Martin Erhard was among them.

With the aid of the city of Peissenberg and the neighbour who passed the drawings to Arnulf Rainer and Galerie Susanne Zander, some information about Martin Erhard emerged. Martin Erhard was born on April 30, 1907 in Peissenberg/Upper Bavaria. He was an employee of the mine and mainly worked underground. Due to his artistic talent, he was reportedly offered a job at the drawing office of the mine's management at one point. He was not able to cope with the unfamiliar situation for long, however, and was consequently sent back to work belowground. According to his neighbours, he was quite the eccentric and - despite not suffering from any kind of mental handicap in the narrower sense - apparently matched all the characteristics one would generally associate with a so-called simple mind. Erhard had little to no contact to his fellow human beings, remained single, and lived with his - likewise unmarried - sister. He spent the last years of his life in the local nursing home for the elderly and died in Peissenberg on December 15, 1979. It is reported that he preferred the night shifts in the mine. As far as it is remembered, he usually wore rubber boots. All in all, he seems to have been a rather inconspicuous person. Furthermore, it is said that he liked to draw on tunnel walls and mining carts in the coalmine.

Besides the railroad track, the Art Brut-collection 'collecting madness' features a second depiction of the 'upper world': a drawing of a train station, whose technically flawless execution forms a decisive contrast to the childlike and faulty writing of the 'underworld' drawings (see Fig. 2). These are represented in the outsider art collection 'collecting madness' (http://collecting madness.com/) by two drawings showing torture chambers, and that may illuminate a coexistence of unintegrated inner states. The difference between the upper and the underworld is striking: on the one hand, a detailed topographical account shows the different areas, borders, stations and occasional hoist ways into the underground tunnels alongside the never-ending railroad line. On the other hand, the world below: vast architectural plans outline a 'house for sport, exercise and art, as well as sinful viewing pleasure' and various rooms built for the sole purpose of 'performing any kind of sexual activity' 'perverted men' and 'sadistic women' 'wish and lust for', mapping out a place where torture, leisure and education complement each other.

Erhard's blueprints of an extensive system deep below the surface are not an expression of certain elements of the artist's personal biography alone, however: The dichotomy between upper world and underworld is a seminal topos in Western culture, reaching back well beyond Dante. The fantasy of an inescapable subterranean stronghold evokes visions of fear and terror like Dracula's castle or the palace of Bluebeard ('Schinderburg') ('slavedriver's castle'). In the face of the long road or track, which, on the last sheet, ends in a railway terminus possibly hosting the entrances to the underworld (an assumption supported by floor plan of the station being in almost perfect accordance with the structures below), one is inevitably reminded of the railroad track which lead to the extermination camp in Auschwitz. Furthermore, Erhard's pictures (see 'Underworld'drawings) use a vocabulary eerily similar to the one used in the death camps of the Nazis, employing terms like 'hair removal', 'bugs' and 'fleas'.

As is true with other obsessive Art Brut artists whose work is concerned with children as sexual fetishes (e.g., Henry Darger, Morton Bartlett), the biography of Martin Erhard reportedly shows no sign of him actually having engaged in any kind of violation - his preoccupation with the subject of sadism probably remained a purely imaginative one throughout his life. In psychoanalysis, perversion is seen as a seal of a fragile ego. In the perverted mind, the other is perceived as posing a vital threat to the self, needing to be controlled, dominated, and as in the case of Erhard or de Sade, humiliated and tortured to the outermost extremes (Lackinger, 2008). By mentally transferring his biggest fears and the idea of radical destruction to the other (thus gaining control over the dreaded suffering by imposing it on his fellow human beings), the pervert decontaminates and preserves himself. Because they are a product of inner struggles with power and catastrophisation, these works usually do not possess any kind of sensual or erotic quality. Sexuality is simply one matrix among others used to stage rituals of dehumanisation. Perversion (one of the most impressive examples for this being De Sade's breathtaking opus 'The 120 Days of Sodom') primarily aims at inducing dispassion (Klossowski, 1991). Soul, emotions and heart must be restrained by virtue of geometry, mathematisations, indexing and ever growing lists of increasingly cruel ordeals. 
In line with Camus' Sisyphus, one should not think of Martin Erhard as a happy man - nevertheless, and although he preferred the depths of his pit over the bright lights of the drawing office, and as a stable one. Coldness and obsession (Dichter et al. 1999) make Erhard's imposing oeuvre repulsive and fascinating at the same time.

\section{References}

Biller M, Stippel L (2006). Bergbau und Bergbau-Museum am Hohen Peißenberg Ein Führer durch die Geschichte der Bergbaus im Bereich des Bayerischen Rigi, 3rd edn. Verein “Bergbaumuseumsfreunde Peißenberg e. V." \& Markt: Peißenberg.

Dichter C, Kittelmann U, Zander S (1999). Obsession. Morton Bartlett, Eugene von Bruenchenhein, Henry Darger, Paul Humphrey, DuMont Kunstverlag, Cologne.

Galerie Susanne Zander (2012). Heim der Liebe und der Sünde", HD, 7:13 min, Cologne. http://www.youtube.com/ watch?v=7cZQmnA0KpE.

Klossowski P (1991) Sade my Neighbor. Northwestern University Press: Evanston, Illinois.
Lackinger F (2008). Zur Dynamik von Perversion und Übertragung. In Psychodynamische Psychotherapie bei Delinquenz (ed. F Lackinger, G Dammann and B Wittmann). Schattauer: Stuttgart, 197-217.

Museum De Stadshof (1996). Collectie Arnulf Rainer. Catalogue, Museum De Stadshof Zwolle: Zwolle.

\section{About the author}

Gerhard Dammann, MD, MSc, MA, MBA is a psychiatrist, clinical psychologist and a psychoanalyst (IPA). $\mathrm{He}$ is the director of the Psychiatric Hospital of Münsterlingen (founded 1839) at the border of the Lake of Constance in Switzerland. He is Privatdozent for psychiatry and psychotherapy at the Medical University of Salzburg and a Honorary Professor. His clinical and scientific areas of interest are the diagnosis and psychotherapy of severe personality disorders. He collects outsider art together with his wife and has written about psychopathology of expression.

Carole Tansella, Section Editor 